UDC 332.05.025

JEL Classification: E61, 014, 033

DOI: $10.15587 / 2706-5448.2021 .238959$

Article type «Reports on Research Projects»

\section{Olena Trofymenko}

\title{
DEVELOPMENT OF A MECHANISM FOR IMPLEMENTATION OF A NATIONAL INNOVATIVE POLICY IN THE ENERGY SECTOR BASED ON INDUSTRY 4.0
}

The object of research is the processes of formation and implementation of mechanisms for innovative development of the energy sector of the national economy in the context of the fourth industrial revolution. It was determined that at the global level, mechanisms for innovative development of industry and energy are formed in the New Industrial Strategy of the European Union (EU), the Paris Climate Agreement, and the fourth energy package of the EU. The challenges of Industry 4.0 necessitate the formation and adaptation of these mechanisms in individual countries to ensure the innovative development of the energy sector in different countries.

In the course of the study, the scientific and applied foundations of ensuring the development of the energy sector at the state level have been analyzed. They also used a system-functional approach, methods of structural and functional analysis and functional synthesis, critical analysis of regulatory framework, goals and objectives in the energy sector of the national economy. As a result, a comprehensive mechanism for the implementation of the national innovation policy in the energy sector of the national economy at various levels of the social hierarchy has been proposed. In particular, 5 functional components of the innovative development of the energy sector of the national economy have been identified:

1) productivity of innovation;

2) effectiveness of innovation policy;

3) effectiveness of energy innovation;

4) investment support for innovative development of the energy sector;

5) development of human capital in terms of decarbonization of the economy.

On the basis of these components, the main mechanisms have been formed, which make up a comprehensive mechanism for implementing the state policy of innovative development of the energy sector of the national economy, and each of these mechanisms has its own set of implementation tools: economic; motivational; organizationaltechnological and political-legal. This forms the basis for the implementation of its interfunctionality and ensures its functioning, based on the principle of multilevel (elements relate to the supranational, interstate, national, regional, local and sectoral levels) and is intended to enhance the socio-economic effects of Industry 4.0.

Keywords: energy innovations, mechanisms of innovative development, national economy, Industry 4.0, energy sector.

\section{How to cite}

Trofymenko, O. (2021). Development of a mechanism for implementation of a national innovative policy in the energy sector based on Industry 4.0. Technology Audit and Production Reserves, 4 (4 (60)), 34-40. doi: http://doi.org/10.15587/2706-5448.2021.238959

\section{Introduction}

Today, the energy sector is undergoing a transformation at a global level. This is due to the new challenges and opportunities of Industry 4.0, as well as the needs for sustainable development. Innovative technologies in the energy sector play an important role in achieving the global sustainable development goals, in particular Goal 7 «Renewable Energy». Developing a mechanism to ensure a favorable innovation ecosystem based on neo-industrialization will accelerate the achievement of these goals and lead to the transition to the fourth industrial revolution. The development of innovations in the energy sector provides an opportunity to achieve the goals of the Paris Climate Agreement, within the framework of the United Nations Framework Convention on Climate Change (UNFCCC) to regulate measures to reduce emissions of carbon dioxide. In turn, this requires the formation of an effective and efficient mechanism for implementing the policy of innovative development of the energy sector, taking into account the complexity and multifunctionality of the mechanism in order to increase the socio-economic effects of Industry 4.0, determines the relevance of this study. 
Scientists have investigated the formation of mechanisms in the field of ensuring the development of the economy, innovative development. So, in work [1] «mechanism» is defined as a set of aggregated states and processes that make up a socio-economic phenomenon. The work [2] defines two main approaches to the interpretation of the essentialmeaningful characteristics of the concept of «mechanism»:

1) structural and organizational (positions the mechanism through the prism of aggregation of individual components, processes and phenomena);

2) structural and functional (along with the organizational structure, focused on the implementation of the strategic goal of the formation of the mechanism).

In the segment of innovative energy development, the term «mechanism» is understood as an organizational and managerial toolkit for the implementation of systemic shifts in the energy sector, accelerating the pace of restructuring of the national economy and increasing the level of efficiency in the use of energy resources in the process of forming a value chain. The work [3] defines the mechanism of innovative development as an integral interconnected set of principles, methods and forms of design, development, implementation and capitalization of innovations. The mechanism of innovative development is determined as a dynamic integrated system of interrelated components and elements that form the parameters of the effective development of an object based on the activation of its innovative activity $[4,5]$. Scientists note the relationship between the level of informatization and innovative activity of enterprises, determine the role of the ecological component in ensuring the innovative development of the economy [6, 7].

Modern foreign articles [8] investigate the mechanisms of diffusion (diffusion) of innovative technologies for the development of the energy sector, note the directions for the development of energy innovations by combining mechanisms of state support for new energy technologies and renewable energy technologies [9], studies show that the combination of technological transformations and mechanisms state support contributes to the development and dissemination of leading energy technologies [10].

At the same time, taking into account the modern conditions of the formation of Industry 4.0 requires fundamentally new approaches and additions to the existing approaches to defining and building mechanisms in the chosen field of research. This determined the object of research - the processes of formation and implementation of mechanisms for innovative development of the energy sector of the national economy in the context of the fourth industrial revolution. The aim of research is to substantiate a comprehensive mechanism for implementing the state policy of innovative development of the energy sector of the national economy.

\section{Methods of research}

The study is based on the analysis of the scientific and applied foundations of ensuring the development of the energy sector at the state level. To study the prerequisites and develop a comprehensive mechanism for the implementation of the national innovation policy in the energy sector of the national economy at various levels of the social hierarchy, a system-functional approach, methods of structural-functional analysis and functional synthesis were used.
For the information base, scientific works of recent years have been selected, which largely correspond to the set goal of the study, the regulatory and legal framework in the energy sector.

\section{Research results and discussion}

Ensuring the innovative development of energy is the basis for the development of industry and the modernization of the industrial complex of world economic systems. The main mechanisms were studied on the example of Ukraine, because for the countries of New Europe, bringing the industrial complex to world standards is a priority task to ensure the progress of the national economy in the context of the Fourth Industrial Revolution. A series of global European initiatives to ensure an energy transition towards sustainable development, envisaging innovative energy development to achieve climate neutrality in Europe by 2050, is The European Green Deal. As part of the plan, it is expected that the electrification of the economy and the use of renewable energy will lead to increased employment in these sectors, improved energy efficiency in buildings and construction jobs.

In addition, the New Industrial Strategy of the European Union (EU) [11] includes three key priorities, which are also in line with the European Green Deal:

1) supporting the global competitiveness of the European industry, defining and maintaining a level playing field at the national and global levels;

2) achieving climate neutrality in Europe by 2050;

3 ) ensuring the digital future of Europe.

The strategy defines the main mechanisms for ensuring these priorities. Of course, reducing the energy intensity of products and reducing energy consumption due to advanced technologies is an important component of achieving certain three priorities. An important element of the global mechanism to ensure the acceleration of the energy transition is the world's first classification of environmentally sustainable activities - the so-called «green» EU taxonomy, adopted by the European Commission on June 18, 2020 This taxonomy is based on the scientific criteria of a system that defines the activities for investors that will allow to carry out decarbonization of the economy [12]. This is an important regulatory and legal mechanism to ensure the implementation of innovative projects in the energy sector. All these principles can be characterized as supranational mechanisms for the development of energy and industry for Ukraine. The Association Agreement between Ukraine and the EU also defines a number of mechanisms, in particular, in the energy sector. Based on the already established mechanisms of innovative development of the energy sector for industrial growth, it is advisable to adapt these mechanisms in Ukraine as well. After all, the Strategy for the development of the industrial complex until 2025 has not yet been adopted. And the process of its completion continues.

The main document for defining tasks for achieving energy goals in Ukraine today is the Energy Strategy of Ukraine for the period up to 2035 «Safety, Energy Efficiency, Competitiveness», which defines the mechanisms for improving the energy complex and bringing it to European standards. However, this strategy was approved in 2017, so it may need to be updated taking into account the above supranational mechanisms.

The subjects of the implementation of the national innovation policy in the energy sector are the main bodies 
at the national level with powers in the field of energy policy, in particular, in the field of innovative energy development, and let's define their main functions.

The Ministry of Energy of Ukraine [13] is the central executive body, whose activities are directed and coordinated by the Cabinet of Ministers of Ukraine. The Ministry of Energy is the main body in the system of central executive authorities that ensures the functioning of the fuel and energy complex of Ukraine.

Thus, one of the priority tasks of the Ministry of Energy of Ukraine is integration with the European ENTSO-E system. According to the main provisions of the Strategy and decisions of the European Union until 2020, each of the EU member states should be involved in the European internal market. In addition, 10-year network development plans for ENTSO-E and ENTSO-G (European Network of Electricity Transmission System Operators and Natural Gas Supply) are to be developed. These networks also provide for the provision of appropriate cross-border corridors and safe routes through a specially created Agency for Cooperation of Energy Regulators (ACER - Agency on Cooperation of Energy Regulators). All other stakeholders should also be involved in this process. It is also possible to note that ENTSO-E is actively working to promote the implementation of important aspects of the energy policy to prevent significant problems of network operation safety, energy system adequacy, market integration and transparency. As well as the sustainability of development through the intensification of the integration of renewable energy sources [13].

By the measures of the Ministry of Energy, it is planned that Ukraine will present work in an isolated mode («island» mode) by 2022 in order to prove the stability of the power system. And based on the results, a decision should be made on the integration of power systems [13]. Also, the Ministry of Energy, together with the State Agency for Energy Efficiency, are responsible for the implementation of a number of initiatives aimed at improving the energy efficiency of the economy. This, in particular, concerns the energy efficiency of buildings in the private and public sector, approximation of the legislation of Ukraine and the EU, the introduction of energy efficiency programs for the population.

The Ministry of Economy of Ukraine (Ministry of Economy) will be restored indirectly to ensure the innovative development of the energy sector [14, 15]. So, providing support for projects of international cooperation in the field of energy efficiency and the development of innovations in the energy sector is also indirectly included in the activities of the Ministry of Economy, because the effective functioning of the economy presupposes the efficient allocation of resources, in particular, energy resources. The powers in the field of energy policy are distributed among numerous ministries and institutions, which have their own functional responsibilities and tasks.

The State Agency for Energy Efficiency and Energy Saving of Ukraine (State Energy Efficiency of Ukraine) implement state policy in the field of efficient use of fuel and energy resources, energy conservation, renewable energy sources and alternative fuels [16].

Since the innovative development of the energy sector is a prerequisite for the decarbonization of the economy among the subjects of the implementation of such a policy, the Ministry of Environmental Protection and Natural Resources of Ukraine was also identified, which ensures the formation and implements of the state policy in the field of environmental protection. In particular, it regulates the negative anthropogenic impact on climate change and adaptation to its changes and fulfills the requirements of the UN Framework Convention on Climate Change and the Kyoto Protocol thereto, the Paris Agreement.

One of the subjects of the implementation of the policy of innovative development of energy is also the National Commission for state regulation in the fields of energy and utilities (NCSREU, Regulator) [17]. The State Inspectorate for Energy Supervision of Ukraine [18] is the central executive body, which activities are directed and coordinated by the Cabinet of Ministers of Ukraine through the Minister of Energy, which implements the state policy in the field of supervision (control) in the field of electricity and heat supply.

It should also be noted that the Cabinet of Ministers of Ukraine (CMU) is the highest executive body responsible for making collective decisions and overseeing state policy in the energy sector and in the field of electricity.

In addition to certain national authorities, which are subjects of state regulation in the field of national energy policy, other levels of policy implementation are determined by subjects of state regulation at the appropriate levels - regional, local, and sectoral. Taking into account the complexity and multi-level nature of the policy of innovative development of the energy sector, there are detailed and proposed mechanisms at different levels of the social hierarchy: supranational, interstate, national, regional, local and sectoral/inter-sectoral.

Thus, the supranational level of energy regulation, in particular, renewable energy, is determined by the main requirements of the EU and world programs to achieve low-carbon production and decarbonization of the economy. Within the framework of the obligations undertaken under the Association Agreement with the EU, the Treaty on the Establishment of the Energy Community, the third and fourth EU energy packages, Ukraine must fulfill its legal and regulatory obligations in the energy sector.

Thus, in order to meet the EU requirements and meet their energy supply needs, let's propose a comprehensive mechanism for the implementation of the national innovation policy in the energy sector. Its complexity is due to management at different levels of the social hierarchy (interstate, state, regional, sectoral, inter-sectoral, local), Fig. 1. This will enhance the socio-economic effects of Industry 4.0.

Fig. 1 presents a comprehensive mechanism for the implementation of the state policy of innovative development of the energy sector of the national economy. The specificity of this mechanism, on the one hand, is due to the socioeconomic effects of Industry 4.0, and on the other hand, the effective functioning of this mechanism is an auxiliary basis for accelerating the socio-economic effects of Industry 4.0 and the emergence of new ones. These socio-economic effects of Industry 4.0 include:

- growth in the rate of implementation of Smart-technologies;

- spread of advanced IT technologies in business processes and various spheres of society's life, which change the basic features of socio-economic life and increase communication capabilities;

- transformational shifts in the direction of global digitalization, which is accompanied by cardinal changes in the systems of production, consumption, marketing and sales; - formation of a hybrid environment, in which new economically social subsystems are created on the basis 
of modern IT technologies, adapted to interaction through digitized financial and material resources and functionally aimed at generating additional value. At the same time, among the main markets of Industry 4.0 are energy, manufacturing and processing industries. Thus, the growing demand for electricity and new opportunities for Industry 4.0 determine the need for fundamentally new approaches to the development of energy and the introduction of energy innovations.
Note that the innovative development of the energy sector of the national economy is influenced by supranational mechanisms and the global ecosystem of innovations. These include the Paris Climate Agreement, the Fourth Energy Package, the EU's New Industrial Policy, the European Deal, which defines the main mechanisms for promoting innovation at the global level. Taking into account the existing global trends, national mechanisms need to be developed and clarified, taking into account the resource potential, opportunities and threats in Ukraine.

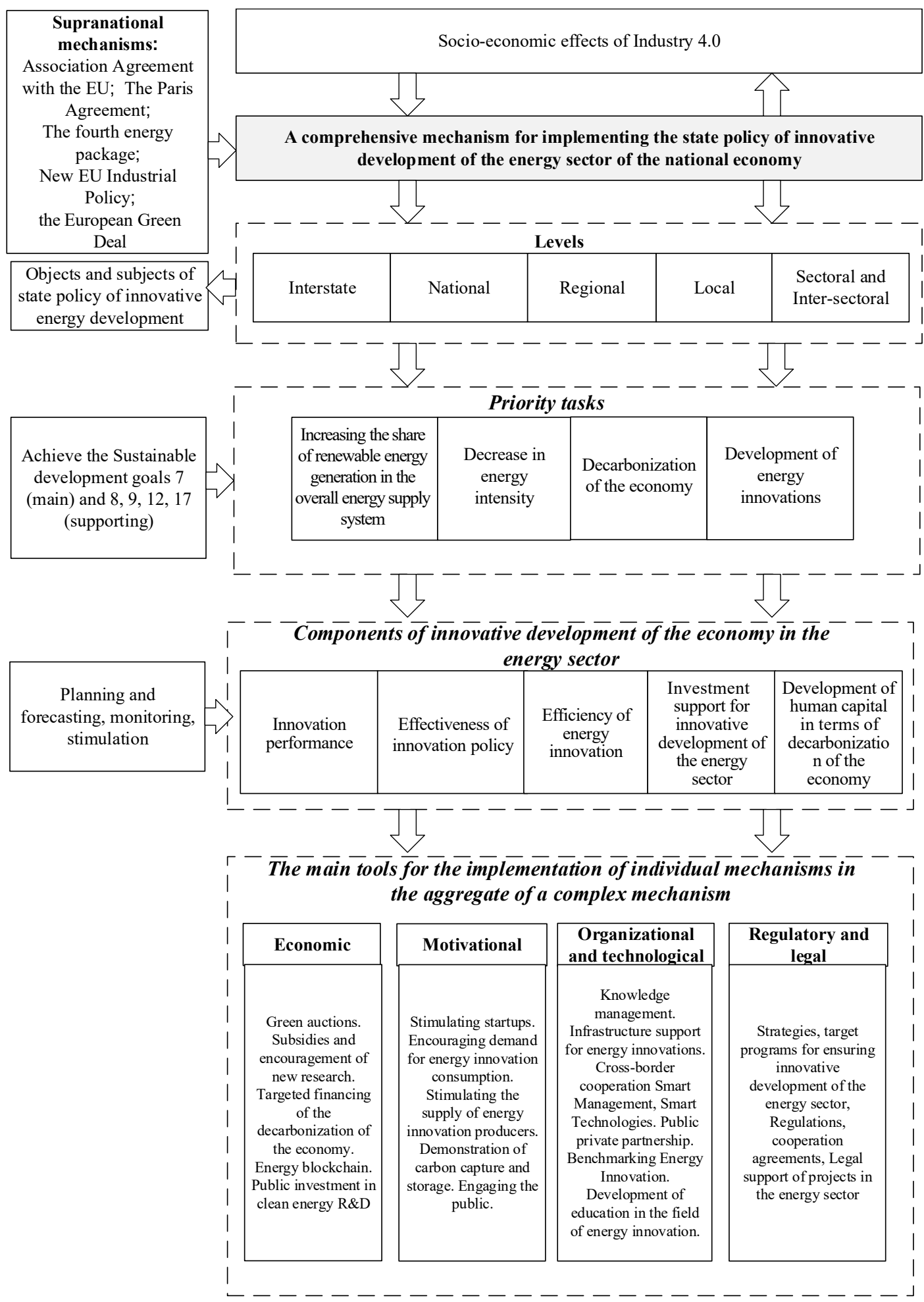

Fig 1. A comprehensive mechanism for the implementation of the state policy of innovative development of the energy sector of the national economy 
That is why, for the effective implementation of the state policy of innovative development of the energy sector of the national economy, it is advisable to apply mechanisms at different levels of the social hierarchy - interstate, national, regional, local, sectoral and inter-sectoral levels. At the same time, each level is characterized by specific objects and subjects, on which approaches to the development of managerial decisions depend, as well as the use of specific analytical tools. Thus, at the interstate level, it is important to apply effective principles of international cooperation. It was found that in order to ensure the innovative development of the energy sector, it is advisable to carry out a taxonomic analysis of the possibilities of cooperation for the development of renewable energy, to provide an opportunity to determine the level of development and feasibility of cooperation, in particular, to achieve the goals of sustainable development (Goal 12, Goal 7). At the national level, the factors influencing the innovative development of the energy sector of the national economy were identified, which will allow monitoring individual components of the innovative development of the energy sector of the national economy and promptly formulating tasks to increase their level of efficiency.

At the regional level, it is advisable to use cluster analysis to determine the level of decarbonization using indicators of decarbonization of the economy. This will make it possible to formulate policies at the level of local self-government bodies, as well as determine sectoral and intersectoral features.

Regardless of the levels of government policy, the following priorities were identified in the direction of ensuring the innovative development of the energy sector:

- increasing the share of renewable energy genera-

tion (RES) in the overall energy supply system;
- reducing the level of energy intensity;

- decarbonization of the economy and the development of energy innovations.

These objectives are critical to the achievement of global Goal 7. At the same time, ensuring the achievement of Goals $8,9,12$ and 17 will provide the appropriate infrastructure to achieve them.

These tasks should be reflected in certain components of the innovative development of the economy in the energy sector:

- productivity of innovation;

- effectiveness of innovation policy;

- efficiency of energy innovations;

- investment support for innovative development of the energy sector;

- development of human capital in terms of decarbonization of the economy.

At the same time, the definition of these components made it possible to form the main mechanisms that make up a comprehensive mechanism for implementing the state policy of innovative development of the energy sector of the national economy. Each of these mechanisms has its own set of implementation tools:

- economic;

- motivational;

- organizational and technological;

- political and legal.

Using the tools of certain mechanisms, specific measures of state policy should be implemented at different levels of government. Within the framework of this study, analytical tools were used to analyze the factors influencing the formation of state policy measures for the innovative development of the energy sector of the national economy (Table 1).

Implementation of measures to ensure the innovative development of the energy sector of the national economy in the context of Industry 4.0

\begin{tabular}{|c|c|c|}
\hline State authorities & Current state & Recommended activities \\
\hline $\begin{array}{l}\text { Cabinet of Ministers of } \\
\text { Ukraine (CMU) on the } \\
\text { proposal of the Ministry of } \\
\text { Economy, the Ministry of } \\
\text { Energy and the involve- } \\
\text { ment of the State Energy } \\
\text { Efficiency and representa- } \\
\text { tives of the public }\end{array}$ & $\begin{array}{c}\text { The National Renewable Energy Action Plan until } 2020 \text { is still in effect. } \\
\text { The development of renewable energy sources is included in the func- } \\
\text { tioning Energy Strategy until } 2035\end{array}$ & $\begin{array}{l}\text { A comprehensive strategy for the functioning of the } \\
\text { renewable energy sector until } 2030 \text {. Given the active } \\
\text { development of hydrogen energy in the world, the tech- } \\
\text { nological capabilities of Industry } 4.0 \text { and the challenges } \\
\text { associated with the loss of liquidity in the energy } \\
\text { market and the change in the structure of the national } \\
\text { economy due to the COVID-19 pandemic. } \\
\text { Integration into the European Green Deal strategy }\end{array}$ \\
\hline Verkhovna Rada, CMU & $\begin{array}{l}\text { Inconsistency of some laws and regulations. The Law of Ukraine «On } \\
\text { stimulating investment activities in priority sectors of the economy in or- } \\
\text { der to create new jobs» [19] indicates that it is aimed at creating condi- } \\
\text { tions for enhancing investment activities by concentrating state resources } \\
\text { on priority areas of economic development in order to introduce the } \\
\text { latest and energy-saving technologies, creation of new jobs, development } \\
\text { of regions. Article } 2 \text { of this law states that the priority sectors of the } \\
\text { economy are sectors aimed at meeting the needs of society in high-tech } \\
\text { competitive environmentally friendly products, high-quality services that } \\
\text { implement the state policy for the development of production and export } \\
\text { potential, and the creation of new jobs. It is also indicated that this list is } \\
\text { determined by the Cabinet of Ministers in accordance with the order of } \\
\text { the Cabinet of Ministers "On approval of the list of priority sectors of the } \\
\text { economy» [20] }\end{array}$ & $\begin{array}{l}\text { Unify regulations on innovation in the energy sector. } \\
\text { Define renewable energy not only as a priority area } \\
\text { of innovation in accordance with the law "On Priority } \\
\text { Areas of Innovation», but also as a promising industry } \\
\text { for investment in the context of jobs. } \\
\text { Consider that, as evidenced by the results of the Global } \\
\text { Energy System based on } 100 \% \text { Renewable Energy } \\
\text { report, presented by experts from the Lappeenranta } \\
\text { University of Technology Finland and the Energy Watch } \\
\text { Group, the global transition to a } 100 \% \text { renewable } \\
\text { electricity system will create more than } 36 \text { million } \\
\text { direct jobs in the energy sector by } 2050 \text { - an increase } \\
\text { from } 19 \text { million jobs added in } 2015\end{array}$ \\
\hline Ministry of Economy & $\begin{array}{l}\text { The strategy for the development of the industrial complex until } 2030 \\
\text { has not been determined, the draft approval of the strategy for the } \\
\text { development of the industrial complex of Ukraine for the period until } \\
2025 \text { has not been agreed since } 2018 \text {. At the same time, an updated } \\
\text { EU industrial strategy was presented by the European Commission, } \\
\text { provides for organizational and regulatory measures to stimulate the } \\
\text { innovative development of European industry in the context of recovery } \\
\text { from the COVID-19 crisis, and also takes into account Industry } 4.0\end{array}$ & $\begin{array}{l}\text { Ensure the development and adoption of a New } \\
\text { strategy for the development of industry in the context } \\
\text { of Industry } 4.0 \text { until 2035, which takes into account } \\
\text { the main opportunities and challenges of the modern } \\
\text { environment, and new technologies in energy supply }\end{array}$ \\
\hline
\end{tabular}


Continuation of Table 1

\begin{tabular}{|c|c|c|}
\hline $\begin{array}{l}\text { CMU, Ministry of Energy, } \\
\text { Ministry of Economy, } \\
\text { Ministry of Regional } \\
\text { Development }\end{array}$ & $\begin{array}{c}\text { At the state level, support for CCS technologies is not developed. } 74 \\
\text { of the } 190 \text { signatory countries to the Paris Agreement have set their } \\
\text { climate targets and commitments to reduce greenhouse gas emissions } \\
\text { internationally. Along with this, more than } 30 \text { states have publicly } \\
\text { announced the achievement of carbon neutrality, that is, balancing } \\
\text { emissions and absorption }\end{array}$ & $\begin{array}{l}\text { Prioritize the development of carbon capture and stor- } \\
\text { age (CCS) technologies in the Energy Strategy or form } \\
\text { a separate strategy (Norwegian experience). Introduce } \\
\text { a national research program to support CCS technolo- } \\
\text { gies (following the example of CLIMIT) in Norway as a } \\
\text { direction for decarbonizing the economy. } \\
\text { Introduce pilot projects in clusters of regions with high } \\
\qquad \mathrm{CO}_{2} \text { levels and developed industry }\end{array}$ \\
\hline $\begin{array}{l}\text { Ministry of Economy, } \\
\text { Ministry of Finance, } \\
\text { Ministry of Education, } \\
\text { Ministry of Energy }\end{array}$ & $\begin{array}{l}\text { Partnership for the achievement of sustainable development goals is } \\
\text { important, but there is little partnership in Ukraine to achieve Goal } 7\end{array}$ & $\begin{array}{l}\text { Joining the alliances «Climate Ambition Alliance: } \\
\text { Net Zero 2050" and "Race to Zera», which brought } \\
\text { together more than } 1000 \text { companies, investors and } \\
\text { universities from } 120 \text { countries of the world, which } \\
\text { will allow to join global research and attract investors } \\
\text { to joint projects. Also, the involvement of universities in } \\
\text { alliances to contribute to the development of component } \\
\text { part } 5 \text { «Human development in terms of decarboniza- } \\
\text { tion» }\end{array}$ \\
\hline \multirow{3}{*}{$\begin{array}{l}\text { Local self-government } \\
\text { bodies (LSB) }\end{array}$} & $\begin{array}{l}\text { The second stage of the decentralization reform is being actively imple- } \\
\text { mented, providing financial independence to communities }\end{array}$ & $\begin{array}{l}\text { Apply GIS technologies for inventorying free land in a } \\
\text { community for a project for the construction of a solar } \\
\text { power plant. Attract an investor. Income - tax on profit } \\
\text { from the project to the community and tax on land }\end{array}$ \\
\hline & $\begin{array}{l}\text { Insufficient dissemination of information on energy innovation, the } \\
\text { importance of energy conservation and decarbonization }\end{array}$ & $\begin{array}{l}\text { Information dissemination activities among local com- } \\
\text { munities about the importance of green energy }\end{array}$ \\
\hline & $\begin{array}{l}\text { Low education in rural communities, decline, high aging of the popula- } \\
\text { tion, poor quality of life }\end{array}$ & $\begin{array}{l}\text { Developing youth for the achievement of Goals } 8 \text { and } 9 \\
\text { as a basis for securing the economy in the communi- } \\
\text { ties. Attracting young people to Makerspace training } \\
\text { (Nunavut case, Canada). Community entrepreneurship } \\
\text { development and support }\end{array}$ \\
\hline
\end{tabular}

The main measures are formed to ensure the innovative development of the energy sector of the national economy in the context of Industry 4.0 for various subjects of public administration are shown in Table 1.

These results will accelerate the achievement of the 2030 Global Sustainable Development Goals. The identified recommendations should be reflected in the basic regulatory documents for the start of the functioning of a comprehensive mechanism for the implementation of innovation policy in the energy sector. For the effective implementation of organizational changes in practice, it is necessary to take into account the characteristics of each organizational level and the territorial characteristics of individual regions, the resource potential of communities. For each proposed component, it is advisable to form clear indicators for further monitoring. After all, they should testify to the effectiveness of the functioning of the multilevel mechanism. Perhaps the development of the study consists in determining the target indicators of the effectiveness of the implementation of individual instruments of the mechanism.

\section{Conclusions}

The prerequisites for providing mechanisms for the implementation of the policy of innovative development of the energy sector in the context of Industry 4.0 are determined. The main subjects of state regulation of the energy sector at the national level, their tasks and functions for the development of innovations in the energy sector have been identified. The main regulatory provisions in the field of energy, certain advantages and disadvantage have been analyzed. A comprehensive mechanism for implementing the state policy of innovative development of the energy sector of the national economy is substantiated, which consists of economic, motivational, organizational, technological and regulatory mechanisms. They form the basis for the implementation of the interfunctionality of the complex mechanism and ensure its functioning on the principle of multilevel. The proposed complex mechanism is intended to enhance the socio-economic effects of Industry 4.0.

\section{References}

1. Ponomarenko, V. S., Iastremskaia, E. N., Lutskovskii, V. M. (2002). Mekhanizm upravleniia predpriiatiem: strategicheskii aspekt. Kharkiv: KHGEU, 252.

2. Kryklii, O. A., Maslak, N. H. (2007). Vyznachennia sutnosti ta struktury finansovoho mekhanizmu upravlinnia filiiamy banku. Visnyk Ukrainskoi akademii bankivskoi spravy, 1 (22), 53-58.

3. Tulchynska, S. O. (2008). Funktsionuvannia orhanizatsiino-ekonomichnoho mekhanizmu innovatsiinoho protsesu. Stratehichni priorytety, 1 (6), 89-95.

4. Rohoza, M. Ye., Verhal, K. Yu. (2011). Stratehichnyi innovatsiinyi rozvytok pidpryiemstv: modeli ta mekhanizmy. Poltava: RVV PUET, 136.

5. Voitko, S. (2019). Conception of Industry 4.0 in the Sustainable Growth of Ukraine. 2019 International Conference on Creative Business for Smart and Sustainable Growth (CREBUS). doi: http:// doi.org/10.1109/crebus.2019.8840040

6. Hrynkevych, S. S., Iliash, O. I. (2015) Teoretyko-prykladni aspekty stanovlennia informatsiinoi ekonomiky v Ukraini. Stratehichni prirytety, 1 (34), 56-63.

7. Smolyar, L. H., Ilyash, O. I., Trofymenko, O. O., Dzhadan, I. M. (2021). An environmental component of securing the national economy's innovative development in the Industry 4.0. Regional Economy, 1 (99), 61-71. doi: http://doi.org/10.36818/1562-0905-2021-1-7

8. Wang, H., Sun, B. (2021). Diffusion Mechanism of Leading Technology in the New Energy Industry Based on the Bass Model. Frontiers in Energy Research, 9. doi: http://doi.org/10.3389/fenrg.2021.586787

9. Kumar, R., Agarwala, A. (2016). Renewable energy technology diffusion model for techno-economics feasibility. Renewable and Sustain- 
able Energy Reviewes, 54, 1515-1524. doi: http://doi.org/10.1016/ j.rser.2015.10.109

10. Malone, E., Hultman, N. E., Anderson, K. L., Romeiro, V. (2017). Stories about ourselves: How national narratives influence the diffusion of large-scale energy technologies. Energy Research \& Social Science, 31, 70-76. doi: http://doi.org/10.1016/j.erss.2017.05.035

11. European industrial strategy. Available at: https://ec.europa.eu/ growth/industry/policy_en\#industrial-strategy-2020

12. EU taxonomy for sustainable activities. Available at: https:// ec.europa.eu/info/business-economy-euro/banking-and-finance/ sustainable-finance/eu-taxonomy-sustainable-activities_en

13. Ministerstvo enerhetyky Ukrainy. Available at: http://mpe.kmu.gov.ua/

14. Ministerstoo ekonomiky Ukrainy. Available at: https:// www.me.gov.ua/

15. Pytannia Ministerstva ekonomiky (2014). Postanova Kabinetu Ministriv Ukrainy No. 459. 20.08.2014. Available at: https://zakon.rada gov.ua/laws/show/459-2014-\%D0\%BF\#Text

16. Derzhenerhoefektyonosti Ukrainy. Available at: https://saee.gov.ua/
17. Natsionalna komisiia, shcho zdiisniuie derzhavne rehuliuvannia $u$ sferakh enerhetyky ta komunalnykh posluh (NKREKP). Available at: https://www.nerc.gov.ua/

18. Derzhavna inspektsiia enerhetychnoho nahliadu Ukrainy. Available at: https://sies.gov.ua/

19. Pro stymuliuvannia investytsiinoi diialnosti u priorytetnykh haluziakh ekonomiky z metoiu stvorennia novykh robochykh mists (2013). Zakon Ukrainy No. 5205-VI. 06.09.2012. Vidomosti Verkhovnoi Rady (VVR), 32, 410. Available at: https://zakon.rada.gov.ua/ laws/show/5205-17\#Text

20. Pro zatverdzhennia pereliku priorytetnykh haluzei ekonomiky (2013). Rozporiadzhennia Kabinetu Ministriv Ukrainy No. 843r. 14.08.2013. Available at: https://zakon.rada.gov.ua/laws/show/ 843-2013-\%D1\%80\#Text

Olena Trofymenko, PhD, Associate Professor, Head of Department of Economics and Entrepreneurship, International University of Finance, Kyiv, Ukraine, e-mail: o.o.trofymenko@gmail.com, ORCID: https:// orcid.org/0000-0002-2339-0377 